MaPan : Jurnal Matematika dan Pembelajaran

p-ISSN: 2354-6883 ; e-ISSN: 2581-172X

Volume 5, Nomor 1, Juni 2017

\title{
PENGARUH EFIKASI DIRI, HARGA DIRI DAN MOTIVASI TERHADAP HASIL BELAJAR MATEMATIKA PESERTA DIDIK KELAS $X$ SMA NEGERI 1 BULUPODDO KAB. SINJAI
}

\author{
Wahdania'), Ulfiani Rahman'), Sri Sulasteri ${ }^{3 /}$ \\ 1,2,3Fakultas Tarbiyah dan Keguruan UIN Alauddin Makassar \\ 1,2,3Kampus II: Jalan H. M. Yasin Limpo Nomor 36 Samata-Gowa \\ E-mail: ulfiani.rahman@uin-alauddin.ac.id ${ }^{2}$, , sri.sulasteri@gmail.com ${ }^{3}$ )
}

\begin{abstract}
Abstrak
Penelitian ini bertujuan untuk mengetahui kreativitas guru dalam mengajar matematika, mengetahui gaya belajar siswa dalam mata pelajaran matematika, mengetahui hasil belajar matematika, dan mengetahui hubungan antara kreativitas guru dan gaya belajar siswa dengan hasil belajar matematika siawa kelas $X$ SMA Negeri 1 Bontomarannu Kabupaten Gowa. Jenis penelitian ini adalah ex-post facto. Populasi dalam penelitian ini adalah siswa kelas X SMA Negeri 1 Bontomarannu Kabupaten Gowa dengan jumlah 465 siswa sedangkan sampelnya adalah $10 \%$ atau 47 siswa dengan teknik pengambilan sampel yang digunakan yaitu simple random sampling. Instrumen yang digunakan berupa angket dan dokumentasi. Teknik analisis yang digunakan adalah analisis statistik deskriptif dan analisis statistik inferensial. Hasil penelitian menunjukkan bahwa terdapat hubungan antara kreativitas guru dan gaya belajar siswa dengan hasil belajar matematika siswa kelas X SMA Negeri 1 Bontomarannu Kabupaten Gowa. Berdasarkan hasil analisis data menggunakan statistik deskriptif untuk kreativitas guru dan gaya belajar siswa berada pada kategori sedang dengan persentase $76 \%$ dan $66 \%$. Kemudian untuk hasil belajar matematika siswa diperoleh nilai persentase sebesar 55\% yang berada pada kategori sedang. Adapun hasil analisis statistik inferensial (korelasi berganda) diperoleh sig. F Change $<0.05$. Artinya, terdapat hubungan positif penerapan antara kreativitas guru dan gaya belajar siswa secara bersama-sama dengan hasil belajar matematika siswa di SMA Negeri 1 Bontomarannu Kabupaten Gowa.
\end{abstract}

Kata Kunci: Kreativitas Guru, Gaya Belajar Siswa, Hasil Belajar Matematika

$\mathrm{P}$ endidikan memiliki peranan penting karena pendidikan membentuk sumber daya manusia menjadi lebih baik dan berkualitas yang diperlukan dalam pembangunan nasional. Tujuan utama pendidikan adalah mengembangkan potensi yang dimiliki agar menjadi manusia yang lebih baik. Maka dari itu menempuh pendidikan mutlak diperlukan oleh setiap manusia. Hal ini sejalan dengan pengertian pendidikan yang tertuang dalam Undang Undang Nomor 20 Tahun 2003 tentang Sistem Pendidikan 
Nasional adalah usaha sadar dan terencana untuk mewujudkan suasana belajar dan proses pembelajaran agar peserta didik secara aktif mengembangkan potensi dirinya untuk memiliki kekuatan spiritual keagamaan, pengendalian diri, kepribadian, kecerdasan, akhlak mulia, serta keterampilan yang diperlukan dirinya, masyarakat, bangsa dan negara.

Dalam dunia pendidikan formal, pentingnya pengukuran prestasi akademik tidaklah dapat disangsikan lagi. Sebagaimana diketahui, proses pendidikan formal adalah suatu proses yang kompleks yang memerlukan waktu, dana dan usaha serta kerjasama berbagai pihak. Berbagai aspek dan faktor terlibat dalam proses pendidikan secara keseluruhan. Pencapaian peserta didik merupakan indikator dalam mengukur seberapa besar tingkat keberhasilan sistem pendidikan di Indonesia. Pencapaian tersebut dapat dilihat dari hasil belajar yang diperoleh oleh peserta didik. Untuk memaksimalkan pencapaian hasil belajar peserta didik, diperlukan pengoptimalan faktor-faktor yang mempengaruhinya

Salah satu faktor yang terlibat adalah faktor dari dalam diri seseorang, yaitu keyakinan seseorang bahwa ia dapat menguasai situasi dan menghasilkan hasil (outcomes) yang positif. Keyakinan seseorang dalam penguasaan situasi ini disebut dengan Self-efficacy. Self-efficacy merupakan suatu keadaan dimana seseorang yakin dan percaya bahwa mereka dapat mengontrol hasil dari usaha yang telah dilakukan. Selain keyakinan terhadap diri sendiri, hal lain yang penting dalam memaksimalkan pencapaian hasil belajar peserta didik adalah penilaian diri. Penilaian seseorang secara umum terhadap dirinya sendiri baik berupa penilaian negatif maupun penilaian positif yang akhirnya menghasilkan perasaan keberhargaan atau kebergunaan diri dalam menjalani kehidupan disebut dengan self-esteem. Individu dengan self-esteem tinggi tidak mudah terpengaruh pada penilaian orang lain mengenai sifat dan kepribadiannya, baik itu positif maupun negatif.

Selain kedua faktor tersebut, faktor lain yang mempengaruhi hasil belajar peserta didik adalah motivasi. Motivasi bukan merupakan suatu kondisi namun motivasi timbul dari dalam diri manusia sendiri yaitu dengan adanya keinginan untuk dapat mengerjakannya dan menyelesaikan sesuatu dengan baik dan benar. Motivasi dirumuskan sebagai dorongan, baik diakibatkan faktor dari dalam maupun luar, untuk mencapai tujuan tertentu guna memenuhi atau memuaskan suatu kebutuhan.

Berdasarkan hasil wawancara dengan seorang guru mata pelajaran matematika SMA Negeri 1 Bulupoddo menyatakan bahwa hasil belajar 
matematika siswa kelas $\mathrm{X}$ memiliki perbandingan yang signifikan antar peserta didik. Hal ini dilihat dari data hasil ulangan tengah semester pada mata pelajaran matematika menunjukkan bahwa $60 \%$ hasil ulangan peserta didik berada pada kategori rendah. Penulis juga melakukan wawancara pada beberapa peserta didik, dan hasilnya menunjukkan bahwa sangat sedikit yang menyukai pelajaran matematika. Ditemukan fakta bahwa banyak peserta didik yang kurang dalam memposisikan seberapa bernilai dirinya dimata teman-temannya. Hal itu dapat terlihat dari masih rendahnya rasa percaya diri dari dalam diri peserta didik, seperti mereka masih belum mampu menentukan cita-cita dan target yang mereka inginkan untuk kedepannya, di dalam proses belajar mengajar mereka juga masih malu-malu dalam mengeluarkan pendapat, bahkan tidak jarang mereka hanya diam dan mendengarkan. Hal tersebut juga menunjukkan bahwa motivasi peserta didik dalam mengikuti proses pembelajaran matematika di kelas sangat rendah.

Oleh karena itu, penulis tertarik melakukan sebuah penelitian untuk mengetahui seberapa besar pengaruh efikasi diri, harga diri dan motivasi secara bersama-sama terhadap hasil belajar matematika siswa, karena belum pernah dilakukan penelitian yang sama sebelumnya. Selain itu, penelitian ini bertujuan pula untuk mengetahui kreativitas guru dalam mengajar matematika pada siswa kelas X SMA Negeri 1 Bontomarannu Kabupaten Gowa, mengetahui gaya belajar siswa dalam mata pelajaran matematika pada siswa kelas X SMA Negeri 1 Bontomarannu Kabupaten Gowa, mengetahui hasil belajar matematika pada siswa kelas X SMA Negeri 1 Bontomarannu Kabupaten Gowa, dan mengetahui hubungan antara kreativitas guru dan gaya belajar siswa dengan hasil belajar matematika siawa kelas X SMA Negeri 1 Bontomarannu Kabupaten Gowa

\section{HASIL BELAJAR MATEMATIKA}

Belajar merupakan proses menciptakan nilai tambah kognitif, afektif, dan psikomotor bagi siswa. Nilai tambah itu tercermin dari perubahan perilaku siswa menuju kedewasaan. Masing-masing substansi pelajaran menghasilkan perilaku yang berbeda, baik yang nyata maupun yang tersembunyi. Psikolog pendidikan telah mempelajari kognisi, pengajaran, pembelajaran, motivasi, perbedaan individu, dan pengukuran kemampuan siswa.

Menurut Gagne dalam Ratna Wilis, hasil belajar matematika adalah kemampuan-kemampuan yang dimiliki siswa setelah ia menerima 
pengalaman belajar matematikanya atau dapat dikatakan bahwa hasil belajar matematika adalah perubahan tingkah laku dalam diri siswa, yang diamati dan diukur dalam bentuk perubahan pengetahuan, tingkah laku, sikap dan keterampilan setelah mempelajari matematika. Perubahan tersebut diartikan sebagai terjadinya peningkatan dan pengembangan ke arah yang lebih baik dari sebelumnya

Untuk memperoleh hasil belajar yang baik, banyak faktor yang mempengaruhinya. Muhibbin Syah menjelaskan secara global faktor-faktor yang mempengaruhi belajar siswa dapat kita bedakan menjadi tiga macam, yakni:

a. Faktor internal (faktor dari dalam siswa), yakni keadaaan atau kondisi jasmani dan rohani siswa

b. Faktor eksternal (faktor dari luar siswa), yakni kondisi lingkungan disekitar siswa.

c. Faktor pendekatan belajar (approach to learning), jenis upaya belajar siswa yang meliputi strategi dan metode yang digunakan siswa untuk melakukan kegiatan pembelajaran materi-materi pelajaran

\section{EFIKASI DIRI}

Ferridiyanto menjelaskan self- efficacy atau efikasi diri merupakan persepsi individu akan keyakinan atas kemampuannya melakukan tindakan yang diharapkan. Self efficacy memengaruhi apakah individu mencoba untuk membangun kebiasaan yang sehat, sebanyak apakah usaha mereka dalam mengatasi stres, berapa lama mereka di dapat bertahan mengahadapi rintangan, dan berapa banyak stres yang dialami.

Corsini berpendapat bahwa aspek-aspek efikasi diri adalah sebagai berikut.

\section{a. Kognitif}

Kognitif adalah kemampuan individu untuk memikirkan cara-cara yang digunakan, dan merancang tindakan yang akan diambil untuk mencapai tujuan yang diharapkan.

b. Motivasi

Motivasi adalah kemampuan individu untuk memotivasi diri melalui pikirannya untuk melakukan tindakan dan membuat keputusan serta mencapai tujuan yang diharapkan. Motivasi tumbuh dari pemikiran yang optimis dari dalam diri individu untuk mewujudkan tindakan yang diharapkan. Tiap-tiap individu berusaha memotivasi dirinya dengan 
menetapkan keyakinan pada tindakan yang akan dilakukan, mengantisipasi pikiran sebagai latihan untuk mencapai tujuan dan merencanakan tindakan yang akan dilakukan, mengantisipasi pikiran sebagai latihan untuk mencapai tujuan dan merencanakan tindakan yang akan dilaksanakannya

c. Afeksi

Afeksi adalah kemampuan individu untuk mengatasi perasaan emosi yang ditimbulkan dari diri sendiri untuk mencapai tujuan yang diharapkan. Afeksi berperan pada pengaturan diri individu terhadap pengaruh emosi. Afeksi terjadi secara alami dalam diri individu dan berperan dalam menentukan intensitas pengalaman emosional. Afeksi ditujukan dengan mengontrol kecemasan dan perasaan depresif yang menghalangi pola pikir yang benar untuk mencapai tujuan.

d. Seleksi

Seleksi adalah kemampuan individu untuk melakukan pertimbangan secara matang dalam memilih perilaku dan lingkungannya. Individu akan menghindari aktivitas dan situasi yang diyakini melebihi kemampuan yang mereka miliki, tetapi mereka siap melakukan aktivitas menantang dan situasi yang mereka rasa mampu mengendalikannya.

Efikasi diri atau keyakinan kebiasaan diri itu dapat diperoleh, diubah, ditingkatkan, atau diturunkan melalui salah satu atau kombinasi empat sumber, yakni pengalaman menguasai sesuatu prestasi (performance accomplishment), pengalaman vikarius (vicarious experience), persuasi sosial (social persuation) dan pembangkitan emosi (emotional physiological states)

\section{HARGA DIRI}

Adi W. Gunawan mengatakan bahwa harga diri didefinisikan sebagai seberapa suka anda terhadap diri anda sendiri. Semakin anda menyukai diri anda, menerima diri anda, dan hormat pada diri anda sendiri sebagai seseorang yang berharga dan bermakna maka semakin tinggi harga diri anda. Semakin anda merasa sebagai manusia yang berharga, maka anda akan semakin bersikap positif dan merasa bahagia, hal itulah yang dikatakan sebagai harga diri

Harga diri adalah evaluasi terhadap perasaan dan penilaian individu tentang dirinya. Harga diri berpengaruh besar terhadap harapan individu tentang dirinya sendiri dan orang lain. Penilaian tersebut mencerminkan 
sikap penerimaan atau penolakan terhadap diri dan seberapa jauh individu percaya bahwa dirinya berharga.

Menurut Felker aspek-aspek harga diri meliputi:

a. Felling of Belonging (Perasaan Memiliki)

Perasaan memiliki ditunjukkan oleh kemampuan individu bahwa dirinya merupakan bagian dari suatu kelompok dan diterima oleh lingkungannya serta merasa dibutuhkan orang lain. Individu akan memiliki nilai yang positif akan dirinya bila mengalami perasaan diterima atau menilai dirinya sebagai bagian dari kelompoknya. Namun individu akan memiliki nilai yang negatif tentang dirinya bila individu mengalami perasaan tidak diterima.

b. Felling of Worth (Perasaan Berharga)

Perasaan berharga ditunjukkan oleh kemampuan individu menghargai dirinya sendiri, percaya diri dan menerima apa adanya atas keadaan dirinya. Individu yang memiliki perasaan berharga akan menilai dirinya lebih positif dari pada individu yang tidak memiliki perasaan berharga.

c. Felling of Competence (Perasaan Berkompeten)

Perasaan berkompeten ditunjukkan oleh kemampuan individu bahwa dirinya merasa mampu dan memiliki sikap optimis dalam menghadapi masalah kehidupan serta mampu mencapai tujuan hidupnya secara efisien

Self-esteem bukanlah sifat atau aspek tunggal saja, melainkan sebuah kombinasi dari beragam sifat dan perilaku. Dalam bukunya, Maximum Selfesteem, Minchiton menjabarkan tiga aspek self-esteem, yaitu perasaan mengenai diri sendiri, perasaan terhadap hidup serta perasaan dalam kaitannya dengan orang lain.

\section{MOTIVASI}

Menurut Hamalik, motivasi adalah suatu perubahan energi di dalam pribadi seseorang yang ditandai dengan timbulnya afektif (perasaan) dan reaksi untuk mencapai tujuan. Dengan kata lain, seseorang mempunyai tujuan tertentu dari segala aktivitasnya. Demikian juga dalam proses belajar, seseorang yang tidak mempunyai motivasi belajar, tidak akan mungkin melakukan aktivitas belajar dan prestasi akademiknya pun akan rendah. Sebaliknya, seseorang yang mempunyai motivasi belajar, akan dengan baik melakukan aktivitas belajar dan memiliki prestasi akademik yang lebih baik. 
Menurut Chernis dan Goleman dalam Sardiman, aspek-aspek dalam motivasi belajar meliputi 6 hal, yaitu:

a. Kesenangan kenikmatan untuk belajar

Berarti menaruh perhatian dan minat terhadap kegiatan-kegiatan itu dan merasa senang sewaktu mengerjakan tugas-tugas sekolah

b. Orientasi terhadap penguasaan materi

Suatu kemampuan yang diperoleh siswa dengan menguasai materi-materi yang disajikan di sekolah.

c. Hasrat ingin tahu

Keinginan siswa yang mewakili motivasi untuk mencari hal-hal baru dan mencarinya lebih jauh lagi.

d. Keuletan dalam mengerjakan tugas

Siswa memusatkan perhatian sepenuhnya untuk menyelesaikan tugas dan tidak mudah menyerah atau putus asa.

e. Keterlibatan yang tinggi pada tugas

Siswa tekun dalam mengerjakna tugas, berkonsentrasi pada tugas dan meluangkan waktu untuk belajar.

f. Orientasi terhadap tugas-tugas

Orientasi terhadap tugas-tugas yang menantang, sulit dan baru, siswa termotivasi untuk menyelesaikan tugas sulit ataupun baru daripada tugas mudah atau rutin.

\section{METODE PENELITIAN}

Jenis dari penelitian ini adalah penelitian ex-postfacto. Jenis penelitian ini digunakan karena pada penelitian ini peniliti tidak memberikan perlakuan terhadap variabel yang diteliti. Karena itu, penelitian ini memerlukan waktu yang relatif singkat. Pendekatan yang digunakan peneliti adalah pendekatan kuantitatif. Dimana penelitian kuantitatif adalah jenis penelitian yang menghasilkan penemuan- penemuaan yang dapat dicapai (diperoleh) dengan menggunkan prosedur-prosedur statistik atau cara-cara lain dari kualifikasi (pengukuran).

Populasi dalam penelitian ini adalah seluruh siswa kelas X SMA Negeri 1 Bulupoddo tahun ajaran 2015/2016 yang terdiri dari 5 kelas yaitu $X$ A, X B , X C, X D, dan X E dengan jumlah peserta didik sebanyak 159 orang. Teknik Pengambilan sampel dalam penelitian ini adalah teknik simple random sampling dari setiap kelas yang ada. Setiap kelas masing-masing diambil 8 orang, terdiri dari 4 orang peserta didik laki-laki dan 4 orang peserta didik 
perempuan Karena setiap anggota populasi mempunyai kesempatan sama untuk bisa dipilih menjadi sampel (populasi bersifat homogen). Instrumen yang digunakan dalam penelitian ini adalah skala efikasi diri, skala harga diri dan skala motivasi.

\section{HASIL PENELITIAN DAN PEMBAHASAN}

\section{Efikasi Diri Peserta Didik Kelas X SMA Negeri 1 Bulupoddo Kabupaten Sinjai}

Berikut ini adalah tabel hasil analisis deskriptif data efikasi diri peserta didik kelas X SMA Negeri 1 Bulupoddo Kab. Sinjai.

Tabel 1. Efikasi Diri Peserta Didik Kelas X SMA Negeri 1 Bulupoddo Kabupaten Sinjai

\begin{tabular}{cc}
\hline Statistik & Skor Statistik \\
\hline Sumpel & 4 \\
Skor Terendah & 4 \\
Skor Tertinggi & 8 \\
Rata-rata & 58,80 \\
Standar Deviasi & 9,45 \\
\hline
\end{tabular}

Berdasarkan tabel descriptive statistics menunjukkan bahwa efikasi diri peserta didik kelas X SMA Negeri 1 Bulupoddo Kab. Sinjai yang didapatkan melalui instrumen skala menunjukkan bahwa skor tertinggi 85 dan skor terendah adalah 43. Skor rata-rata yang diperoleh adalah 58,80 sehingga efikasi diri peserta didik berada kategori cukup.

\section{Harga Diri Peserta Didik Kelas X SMA Negeri 1 Bulupoddo Kabupaten Sinjai}

Berikut ini adalah tabel hasil analisis deskriptif data harga diri peserta didik kelas X SMA Negeri 1 Bulupoddo Kab. Sinjai.

Tabel 2. Harga Diri Peserta Didik Kelas X SMA Negeri 1 Bulupoddo Kabupaten Sinjai

\begin{tabular}{cc}
\hline Statistik & Skor Statistik \\
\hline Sampel & 40 \\
Skor Terendah & 42 \\
Skor Tertinggi & 86 \\
Rata-rata & 64,07 \\
Standar Deviasi & 10,43 \\
\hline
\end{tabular}


Berdasarkan tabel descriptive statistics menunjukkan bahwa harga diri peserta didik kelas X SMA Negeri 1 Bulupoddo Kab. Sinjai yang didapatkan melalui instrumen skala menunjukkan bahwa skor tertinggi 86 dan skor terendah adalah 42. Skor rata-rata yang diperoleh adalah 64,07 sehingga harga diri peserta didik berada kategori cukup

\section{Motivasi Peserta Didik Kelas X SMA Negeri 1 Bulupoddo Kabupaten Sinjai}

Berikut ini adalah tabel hasil analisis deskriptif data motivasi peserta didik kelas X SMA Negeri 1 Bulupoddo Kab. Sinjai.

Tabel 3. Motivasi Peserta Didik Kelas X SMA Negeri 1 Bulupoddo Kabupaten Sinjai

\begin{tabular}{cc}
\hline Statistik & Skor statistik \\
\hline Sampel & 40 \\
skor terendah & 42 \\
skor tertinggi & 78 \\
Rata-rata & 59,85 \\
Standar Deviasi & 8,95 \\
\hline
\end{tabular}

Berdasarkan tabel descriptive statistics menunjukkan bahwa motivasi peserta didik kelas X SMA Negeri 1 Bulupoddo Kab. Sinjai yang didapatkan melalui instrumen skala menunjukkan bahwa skor tertinggi 78 dan skor terendah adalah 42. Skor rata-rata yang diperoleh adalah 59,85 sehingga emotivasi peserta didik berada kategori cukup

\section{Hasil Belajar Matematika Peserta Didik Kelas X SMA Negeri 1 Bulupoddo}

\section{Kabupaten Sinjai}

Berikut ini adalah tabel hasil analisis deskriptif data hasil belajar matematika peserta didik kelas X SMA Negeri 1 Bulupoddo Kab. Sinjai.

Tabel 4. Hasil Belajar Matematika Peserta Didik Kelas X SMA Negeri 1 Bulupoddo Kabupaten Sinjai

\begin{tabular}{cc}
\hline Statistik & Skor Statistik \\
\hline Sampel & 4 \\
Skor terendah & 3 \\
Skor tertinggi & 9 \\
Rata-rata & 623 \\
Standar Deviasi & 165 \\
\hline
\end{tabular}


Berdasarkan tabel descriptive statistics menunjukkan bahwa hasil belajar matematika peserta didik kelas X SMA Negeri 1 Bulupoddo Kab. Sinjai yang didapatkan melalui instrumen skala menunjukkan bahwa skor tertinggi 90 dan skor terendah adalah 30. Skor rata-rata yang diperoleh adalah 62,33 sehingga hasil belajar matematika peserta didik berada kategori cukup

\section{Analisis Regresi Linear Berganda}

Pada analisis regresi linier berganda ini digunakan untuk mengetahui pengaruh efikasi diri, harga diri dan motivasi terhadap hasil belajar matematika peserta didik kelas X SMA Negeri 1 Bulupoddo Kab. Sinjai.

Tabel 5. Hasil Analisis Regresi Berganda

\begin{tabular}{cccc}
\hline Variabel & B & T & Si \\
\hline Konstan & $-39,896$ & $-3,947$ & 0,000 \\
Efikasi Diri & 0,492 & 3,0 & 0,034 \\
Harga Diri & 0,686 & 2,2 & 0,001 \\
Motivasi & 0,490 & 2,0 & 0,043 \\
\hline
\end{tabular}

Berdasarkan tabel di atas menunjukkan bahwa model persamaan regresi berganda untuk memperkirakan hasil belajar matematika yang dipengaruhi oleh efikasi diri, harga diri dan motivasi adalah:

$$
Y=-39,896+0,492 X_{1}+0,686 X_{2}+0,490 X_{3}
$$

$\mathrm{Y}$ adalah hasil belajar matematika, $\mathrm{X}_{1}$ adalah efikasi diri, $\mathrm{X}_{2}$ adalah harga diri dan $\mathrm{X}_{3}$ adalah motivasi. Dari persamaan di atas, dapat di analisis beberapa hal antara lain:

Kemampuan hasil belajar matematika, jika tanpa adanya efikasi diri, harga diri dan motivasi $\left(\mathrm{X}_{1}=0, \mathrm{X}_{2}=0\right.$ dan $\left.\mathrm{X}_{3}=0\right)$, maka hasil belajar matematika hanya $-39,896=-40$. Koefisien regresi berganda sebesar 0,492; 0,686 dan 0,490 mengindikasikan bahwa besaran penambahan tingkat hasil belajar matematika setiap pertambahan jawaban siswa untuk variabel efikasi diri, harga diri dan motivasi.

Berdasarkan aplikasi analisis SPSS diperoleh kesimpulan hasil analisis yaitu sebagai berikut:

Tabel 6. Uji Signifikansi Koefisien Regresi Ganda

\begin{tabular}{ccccc}
\hline $\mathbf{R}$ & $\mathbf{R}$ & $\mathbf{F}$ & $\mathbf{S}$ & Kesimpulan \\
\hline 0,865 & 0,748 & 35,591 & 0,000 & Berkorelasi positif dan signifikan \\
\hline
\end{tabular}


Berdasarkan hasil analisis diperoleh nilai $\mathrm{R}$ sebesar 0,748 . Hal ini menunjukkan bahwa terjadi hubungan yang cukup erat antara efikasi diri, harga diri dan motivasi terhadap hasil belajar matematika. Dari hasil analisis data yang dilakukan dapat disimpulkan bahwa terdapat pengaruh yang signifikan (sig. < 0,05) antara efikasi diri, harga diri dan motivasi terhadap hasil belajar matematika peserta didik kelas X SMA Negeri 1 Bulupoddo.

Hasil penelitian menunjukkan bahwa efikasi diri, harga diri dan motivasi berpengaruh positif dan signifikan terhadap hasil belajar matematika peserta didik kelas X SMA Negeri 1 Bulupoddo. Hasil penelitian ini menunjukkan bahwa secara bersama-sama efikasi diri, harga diri dan motivasi berpengaruh secara signifikan terhadap hasil belajar matematika peserta didik kelas X SMA Negeri 1 Bulupoddo. Berdasarkan fakta dan data yang terkumpul, hasil penelitian ini kemudian akan dibahas dan mengaitkannya dengan teori.

\section{Pengaruh Efikasi Diri Terhadap Hasil Belajar Matematika Peserta Didik Kelas X SMA Negeri 1 Bulupoddo}

Setelah melakukan analisis terhadap data yang diperoleh pada penelitian ini, diperoleh bahwa efikasi diri berpengaruh secara signifikan terhadap hasil belajar matematika peserta didik kelas X SMA Negeri 1 Bulupoddo dengan nilai signifikansi sebesar 0,034 . Hal ini sejalan dengan penelitian oleh sitti fitriana menunjukkan bahwa efikasi diri berpengaruh positif terhadap hasil belajar peserta didik. Peserta didik yang memiliki efikasi diri yang tinggi akan mempersiapkan dirinya belajar dengan baik sehingga memperoleh hasil belajar yang baik.

\section{Pengaruh Harga Diri terhadap Hasil belajar Matematika Peserta Didik Kelas X SMA Negeri 1 Bulupoddo}

Setelah melakukan analisis terhadap data yang diperoleh pada penelitian ini, diperoleh bahwa harga diri berpengaruh secara siginifikan terhadap hasil belajar peserta didik kelas X SMA Negeri 1 Bulupoddo Kab. Sinjai dengan nilai signifikansi 0,001. Hal ini sejalan dengan penelitian yang dilakukan oleh Neny Irawati dan Nurahma Hajat menunjukkan bahwa harga diri berpengaruh positif terhadap hasil belajar peserta didik. Peserta didik yang memiliki feeling of competence akan berusaha menjadi yang terbaik, ia tidak akan membiarkan orang lain lebih unggul dibanding 
dirinya, dengan begitu ia akan berusaha yang terbaik untuk mencapai hasil yang terbaik, termasuk dalam pencapaian hasil belajar di sekolah.

\section{Pengaruh Motivasi terhadap Hasil belajar Matematika Peserta Didik Kelas X SMA Negeri 1 Bulupoddo}

Setelah melakukan analisis terhadap data yang diperoleh pada penelitian ini, diperoleh bahwa harga diri berpengaruh secara signifikan terhadap hasil belajar matematika peserta didik kelas X SMA Negeri 1 Bulupoddo Kab. Sinjai dengan nilai signifikansi 0,043. Hal ini sejalan dengan penelitian yang dilakukan oleh Laelah Istiqomah menunjukkan bahwa motivasi belajar berpengaruh positif terhadap hasil belajar peserta didik. . Semakin tinggi tingkat motivasi belajar yang dimiliki peserta didik dapat membuatnya lebih aktif belajar utnuk memperoleh pengetahuan dan memperoleh hasil belajar yang tinggi.

\section{Pengaruh Efikasi Diri, Harga Diri dan Motivasi terhadap Hasil belajar Matematika Peserta Didik Kelas X SMA Negeri 1 Bulupoddo}

Hasil penelitian ini menunjukkan bahwa secara bersama-sama efikasi diri, harga diri dan motivasi berpengaruh secara signifikan terhadap hasil belajar matematika peserta didik kelas X SMA Negeri 1 Bulupoddo. Koefisien determinasi sebesar 74,8\% menunjukkan bahwa 74,8\% hasil belajar matematika siswa dapat dijelaskan oleh efikasi diri, harga diri dan motivasi peserta didik. Sehubungan dengan hal tersebut, maka dalam penelitian ini dapat dikatakan bahwa efikassi diri, harga diri dan motivasi peserta didik memiliki jumlah pengaruh yang besar terhadap hasil belajar matematika peserta didik kelas X SMA Negeri 1 Bulupoddo Kab. Sinjai.

\section{SIMPULAN}

Gambaran efikasi diri peserta didik kelas X SMA Negeri 1 Bulupoddo Kabupaten Sinjai yaitu diperoleh rata-rata sebesar 58,80 berada pada kategori cukup. Begitu pula dengan harga diri peserta didik berada pada kategori cukup dengan rata-rata sebesar 64,07. Sejalan dengan efikasi diri dan harga diri peserta didik motivasi peserta didik juga menempati kategori cukup dengan rata-rata sebesar 59,85. Gambaran hasil belajar peserta didik kelas X SMA Negeri 1 Bulupoddo yaitu diperoleh rata-rata sebesar 62,33 berada pada kategori cukup. Berdasarkan hasil analisis inferensial efikasi diri terhadap hasil belajar peserta didik kelas $\mathrm{X}$ 
SMA Negeri 1 Bulupoddo Kabupaten Sinjai diperoleh bahwa pengaruh efikasi diri terhadap hasil belajar peserta didik dengan nilai signifikansi sebesar 0,034 artinya memberikan pengaruh positif Berdasarkan hasil analisis inferensial harga diri terhadap hasil belajar matematika peserta didik kelas X SMA Negeri 1 Bulupoddo diperoleh diperoleh bahwa pengaruh harga diri terhadap hasil belajar peserta didik dengan nilai signifikansi sebesar 0,001 artinya memberikan pengaruh positif Berdasarkan hasil analisis inferensial motivasi terhadap hasil belajar peserta didik kelas $X$ SMA Negeri 1 Bulupoddo diperoleh bahwa pengaruh motivasi terhadap hasil belajar peserta didik dengan nilai signifikansi sebesar 0,043 artinya memberikan pengaruh positif. Hasil penelitian ini menunjukkan bahwa secara bersama-sama efikasi diri, harga diri dan motivasi berpengaruh secara signifikan terhadap hasil belajar matematika peserta didik kelas X SMA Negeri 1 Bulupoddo. Koefisien determinasi sebesar 74,8\% menunjukkan bahwa $74,8 \%$ hasil belajar matematika siswa dapat dijelaskan oleh efikasi diri, harga diri dan motivasi peserta didik.

\section{DAFTAR PUSTAKA}

Alwisol. (2009). Psikologi kepribadian edisi revisi. Malang: UMM Press.

Arikunto, S. (2010). Dasar-dasar evaluasi pendidikan. Jakarta: Bumi Aksara.

Arikunto, S. (2013). Prosedur penelitian, suatu pendekatan praktis. Jakarta: PT Rineka Cipta.

Bekti, S. A. \& Wahyu A. (2010). Pengaruh efikasi diri, pemanfaatan gaya belajar dan lingkungan teman sebaya terhadap prestasi belajar akuntansi. Surakarta: Universitas Sebelas Maret Surakarta.

Daulay, R. W. (2010). Efikasi diri dan motivasi terhadap keberhasilan usaha pada usaha fotocopy dan alat tulis kantor di Kecamatan Penyabungan Kabupaten Mandailing Natal. Skripsi. Medan: Universitas Sumatera Utara.

Departemen Agama RI. (2006). Qur'an tajwid dan terjemahan. Jakarta: Magfirah Pustaka.

Hadjar, I. (1999). Dasar-dasar metodologi penelitian kuantitatif dalam pendidikan. Jakarta: Raja Grafindo Persada. 
Hasan, M. I. (2008). Pokok-pokok materi statistik 1. Jakarta: PT Bumi Aksara.

Jennifer. (2010). Self-efficacy's influence on student academic achievement in the medical nanatomy curriculum. Columbus: The Ohio State University.

King, L. A. (2010). The science of psychology an appreciative view. Jakarta: Salemba Humanika.

Ni Kadek, S. A. (2008). Pengaruh tingkat intelegensi dan motivasi belajar terhadap prestasi akademik siswa kelas II SMA Negeri 99. Skripsi. Universitas Gunadarma.

Purwanto, A. (2015). Pengaruh efikasi diri terhadap perilaku menyontek siswa kelas V Sekolah Dasar Negeri se-Gugus II Kecamatan Pakem Kab. Sleman. Skripsi.

Purwanto, M. N. (2012). Psikologi pendidikan. Bandung: Remaja Rosdakarya.

Sardiman, A. M. (2006). Interaksi dan motivasi belajar mengajar. Jakarta: PT. Raja Grafindo Persada.

Slameto. (2013). Belajar dan faktor-faktor yang mempengaruhinya. Jakarta: Rineka Cipta.

Sudarwan D., \& Khairil. (2011). Psikologi pendidikan. Bandung: Alfabeta.

Sudjana, N. (2001). Penilaian hasil proses belajar mengajar. Bandung: Remaja Rosdakarya. 